\title{
Increased levels of prolactin receptor expression correlate with the early onset of lupus symptoms and increased numbers of transitional- 1 B cells after prolactin treatment
}

Yadira Ledesma-Soto ${ }^{1,5}$, Francisco Blanco-Favela ${ }^{1}$, Ezequiel M Fuentes-Pananá2 ${ }^{2}$ Emiliano Tesoro-Cruz ${ }^{1,3}$, Rafael Hernández-González ${ }^{3}$, Lourdes Arriaga-Pizano ${ }^{4}$, María V Legorreta-Haquet ${ }^{1}$, Eduardo Montoya-Diaz ${ }^{1}$, Luis Chávez-Sánchez ${ }^{1}$, María E Castro-Mussot ${ }^{5}$ and Adriana K Chávez-Rueda ${ }^{{ }^{*}}$

\begin{abstract}
Background: Prolactin is secreted from the pituitary gland and other organs, as well as by cells such as lymphocytes. Prolactin has an immunostimulatory effect and is associated with autoimmune diseases that are characterised by abnormal B cell activation, such as systemic lupus erythematosus (SLE). Our aim was to determine if different splenic B cell subsets express the prolactin receptor and if the presence of prolactin influences these B cell subsets and correlates with development of lupus.

Results: Using real-time PCR and flow cytometry, we found that different subsets of immature (transitional) and mature (follicular, marginal zone) B cells express different levels of the prolactin receptor and are differentially affected by hyperprolactinaemia. We found that transitional B cells express the prolactin receptor at higher levels compared to mature B cells in C57BL/6 mice and the lupus-prone MRL/Ipr and MRL mouse strains. Transitional-1 (T1) B cells showed a higher level of prolactin receptor expression in both MRL/lpr and MRL mice compared to C57BL/6 mice. Hyperprolactinaemia was induced using metoclopramide, which resulted in the development of early symptoms of SLE. We found that T1 B cells are the main targets of prolactin and that prolactin augments the absolute number of T1 B cells, which reflects the finding that this B cell subpopulation expresses the highest level of the prolactin receptor.

Conclusions: We found that all B cell subsets express the prolactin receptor but that transitional B cells showed the highest prolactin receptor expression levels. Hyperprolactinaemia in mice susceptible to lupus accelerated the disease and increased the absolute numbers of $\mathrm{T} 1$ and $\mathrm{T} 3 \mathrm{~B}$ cells but not of mature $\mathrm{B}$ cells, suggesting a primary effect of prolactin on the early stages of B cell maturation in the spleen and a role of prolactin in B cell differentiation, contributing to SLE onset.
\end{abstract}

\section{Background}

Prolactin (PRL) is a lactogenic hormone that is mainly produced by the anterior pituitary gland. PRL has multiple functions that regulate reproduction, development and growth, osmosis, metabolism of carbohydrates and lipids and the immune system. Each of these functions

\footnotetext{
* Correspondence: akarina_chavez@yahoo.com.mx

'Unidad de Investigación Médica en Inmunología, Hospital de Pediatría, CMN Siglo XXI, IMSS. Av Cuauhtemoc 330. Col. Doctores, Mexico, D.F. CP06720, Mexico

Full list of author information is available at the end of the article
}

requires expression of the PRL receptor in different extra-pituitary regions [1]. In the immune system, interaction between hormones and receptors activates the transcription of genes involved in different cellular functions, such as proliferation, differentiation, and cytokine production [2-4]. PRL has been implicated as a modulator of both cellular and humoral immunity [1-4].

Elevated serum levels of PRL have been reported in several autoimmune diseases, including multiple sclerosis [5] and systemic lupus erythematosus (SLE) [6-9],

\section{Ciomed Central}


although this finding has not been reported for other diseases such as autoimmunity during chronic hepatitis C [10]. Moreover, women with hyperprolactinaemia but without autoimmune disorders have been reported to have circulating autoantibodies [11].

SLE is an autoimmune rheumatic disease. Serum samples from SLE patients characteristically have very strong reactivity to a broad spectrum of nuclear components, including DNA, RNA, histones, RNP, Ro, and La. These antibodies form immune complexes that are deposited in the kidneys and may cause proteinuria and kidney failure. The presence of these autoantibodies indicates abnormalities in the activation and development of B cells [12,13], and both $\mathrm{B}$ and $\mathrm{T}$ cells express the PRL receptor and produce and secrete PRL [1,14-16]. SLE mainly affects women of the reproductive age at a ratio of 9:1 compared to men, and this gender bias has been attributed to the immunostimulatory properties of hormones. SLE symptoms tend to start or become exacerbated during pregnancy, when serum PRL levels are high. High serum concentrations of PRL correlate with SLE activity [6-8], and hyperprolactinaemic patients with antiphospholipid syndrome display significantly more serositis and peritonitis compared to healthy individuals. [9,17]. These findings have also been observed in the murine NZB $\times$ NZW model of lupus after the induction of hyperprolactinaemia, in which the presence of PRL correlates with the early detection of immune complexes, proteinuria, and accelerated death [18].

MRL-MpJFas ${ }^{\text {lpr }}$ (MRL/lpr) mice have a mutation in the Fas gene and develop a disease similar to SLE, characterised by glomerulonephritis, vasculitis, splenomegaly, hypergammaglobulinemia and the production of antidsDNA antibodies [19]. In this strain of mouse, eliminating $\mathrm{B}$ cells using an anti-CD79 antibody decreased manifestations of the SLE-like disease, demonstrating the importance of B cells in SLE physiopathology $[20,21]$. B cells start their maturation process in the bone marrow, undergoing the proB, preB and immature stages, and finish maturation in the spleen, where the transitional and mature B cell subsets can be found. These populations are distinguished by the expression of different surface molecules. Allman et al. classified transitional B cells into three types: transitional-1 (T1 $\left[\mathrm{CD}^{+}{ }^{+}, \mathrm{IgM}^{\text {high }}, \mathrm{CD}^{-} 3^{-}\right]$), transitional-2 (T2 $\left[\mathrm{CD}^{+}{ }^{+}\right.$, IgM $\left.{ }^{\text {high }}, \mathrm{CD}_{23^{+}}\right]$), and transitional-3 (T3 [CD93 ${ }^{+}$, $\left.\left.\mathrm{IgM}^{\text {low }}, \mathrm{CD}^{2} 3^{+}\right]\right)$, while mature $\mathrm{B}$ cells are classified as follicular (FO [CD93- CD21 $\left.1^{\text {int }}, \mathrm{CD} 23^{\text {high }}\right]$ ) or marginal zone (MZ [CD93-, CD21 $\left.{ }^{\text {high }}, \mathrm{CD}^{-} 3^{-}\right]$) [22].

The objective of this study was to determine whether different splenic B cell subsets express the PRL receptor and if the presence of PRL influences these B cells subsets and correlates with the development of lupus. We found that all $B$ cell subsets expressed the PRL receptor but that transitional $\mathrm{B}$ cells displayed higher expression levels compared to mature B cells. Hyperprolactinaemia in mice susceptible to lupus accelerated the disease and increased the absolute numbers of T1 and T3 B cells but not mature B cells, suggesting that PRL participates in the early stages of splenic B cell development.

\section{Results}

Expression of the PRL receptor varies among the different splenic B cell subsets

The follicular, marginal zone, and transitional splenic $B$ cell subsets were purified from C57BL/6 wild-type mice by flow cytometry with greater than $95 \%$ purity (Figure 1) and were assayed for the expression of the PRL receptor at the mRNA and protein levels. We found that splenic B cells expressed the PRL receptor, with transitional $B$ cells showing the highest relative mRNA expression (13.6 \pm 0.2 ). Among the mature B cells subsets, MZ B cells showed approximately two-fold higher expression $(9.3 \pm 0.8)$ than the FO B cells $(5 \pm 0.3)$ (Figure $2 \mathrm{~A})$. At the protein level, we found that transitional $B$ cells expressed the highest level of the PRL receptor $(283.3 \pm 52.4$ MFI [mean fluorescence intensity] $)$, followed by MZ B cells $(173.0 \pm 18.6 \mathrm{MFI})$ and FO B cells

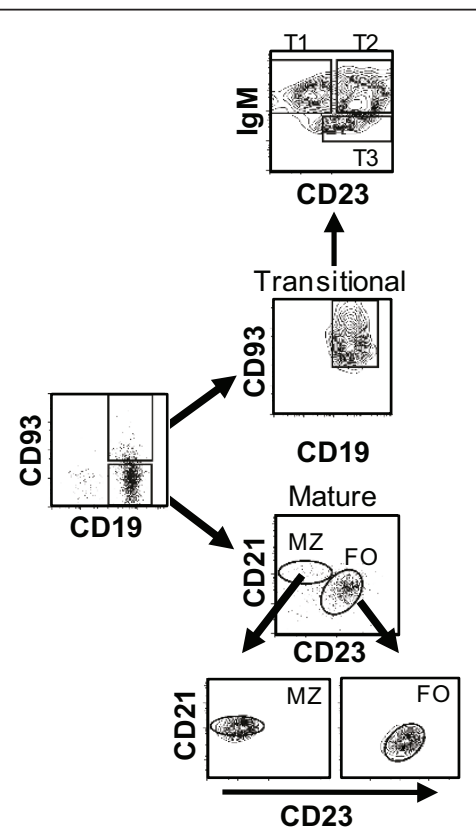

Figure 1 Purification of B cell subsets by flow cytometry. B cells were purified by negative selection from 9-week-old mice. Splenic cells were incubated with different antibodies (anti-CD19, anti-CD93, anti-CD21, anti-CD23, and anti-lgM), and the different B cell subsets were purified by flow cytometry as detailed in the Methods section. The purity of the collected populations oscillated between $95 \%$ and 98\%. A representative example of the purified B cells from wild-type C57BL/6 mice is shown. 
A)

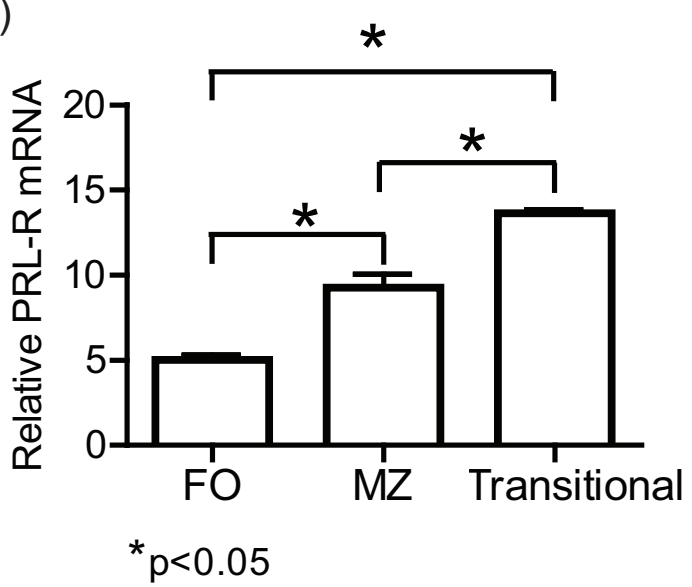

C)

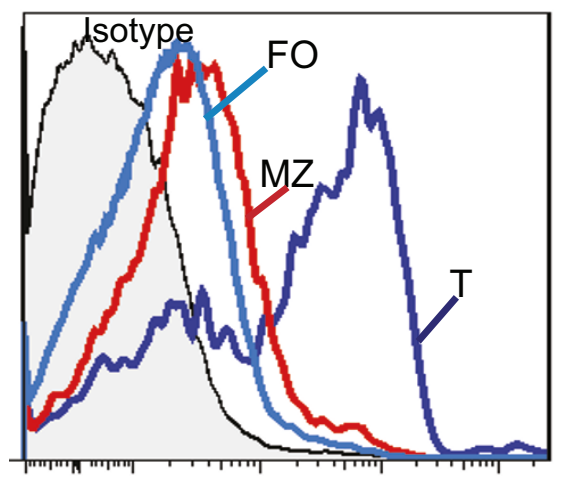

B)

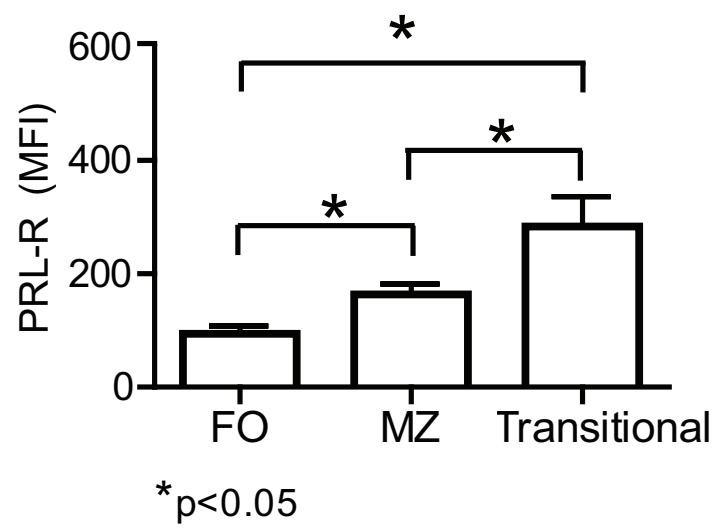

D)

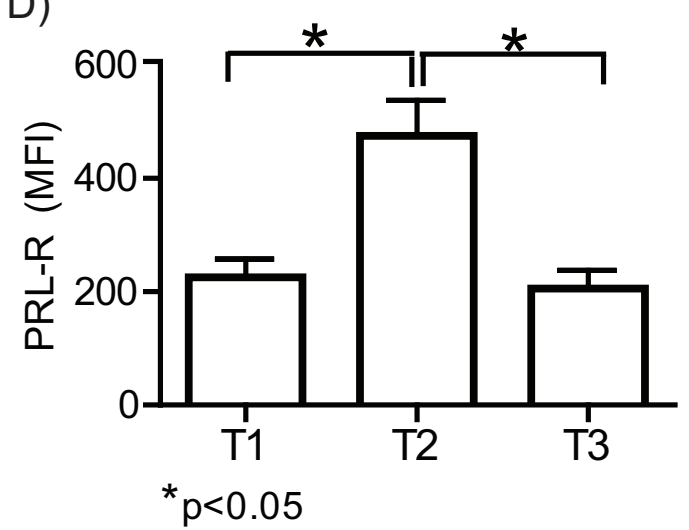

Figure 2 Expression of prolactin receptor in different subsets of splenic B cells from C57BL/6 mice. The different B cell subsets from 9week-old C57BL/6 mice were purified by flow cytometry in four independent experiments using eight mice per experiment. Using real-time PCR, PRL receptor (PRL-R) mRNA expression was determined in the following different subsets of splenic B cells: A) Follicular (FO), marginal zone (MZ), and transitional (T). The protein expression levels of the PRL receptor were determined for ten mice of each strain by flow cytometry, and the mean fluorescence intensity (MFI) is shown in the following B cell subsets: B) Follicular; marginal zone; and transitional. C) Histograms of PRL receptor expression in the different subsets of $B$ cells are shown. D) Transitional 1,2 and 3. The asterisks denote statistical significance with the $p$ value shown.

$(103.0 \pm 16.0 \mathrm{MFI})$, similar to the pattern observed with PRL receptor mRNA expression (Figure $2 \mathrm{~B}$ and $2 \mathrm{C}$ ). Within the transitional subset, T2 B cells showed the highest protein levels of the PRL receptor $(458.7 \pm$ 92.5), followed by T1 (225.2 \pm 32.3$)$ and T3 (208.7 \pm 59.4) B cells (Figure 2D).

When the protein level of PRL receptor among total splenic B cells from C57BL/6 wild-type mice was compared with that in the lupus-prone MRL and MRL/lpr mice, we found a statistically significant $(\mathrm{p}<0.05)$ increase in PRL receptor expression in the MRL mice (two-fold increase; $237.0 \pm 93.8 \mathrm{MFI}$ ) and in the MRL/ lpr mice (three-fold increase; $306.3 \pm 58.1 \mathrm{MFI}$ ) than in the C57BL/6 mice $(96.7 \pm 16.6 \mathrm{MFI})$. The differences in PRL receptor expression between MRL and MRL/lpr mice were also statistically significant $(\mathrm{p}<0.05)$ (Figure $3 \mathrm{~A})$.
When individual B cell subsets were evaluated, we observed a statistically significant increase $(\mathrm{p}<0.05)$ in PRL receptor protein expression in FO B cells from $\mathrm{MRL} / \mathrm{lpr}$ mice $(238.0 \pm 63.5 \mathrm{MFI})$ compared to that in cells from C57BL/6 mice (111.2 $\pm 39.0 \mathrm{MFI})$. PRL receptor expression in MRL mice was only slightly elevated compared to that in C57BL/6 mice. In MZ B cells, there was not a statistically significant difference in PRL receptor protein expression between C57BL/6, MRL and MRL/lpr mice $(190.5 \pm 17.6,201.4 \pm 59.1$ and $266.0 \pm$ 71.9 MFI, respectively). A statistically significant difference in receptor expression was observed in transitional B cells, with MFI of $805.5 \pm 64.6$ in the MRL/lpr strain, $437.5 \pm 82.6$ in MRL strain and $283.5 \pm 41.3$ in the C57BL/6 mice (Figure 3B). Among the transitional B cell subsets, T1 cells displayed the greatest levels of PRL receptor protein expression in MRL/lpr (1105.7 \pm 79.9 


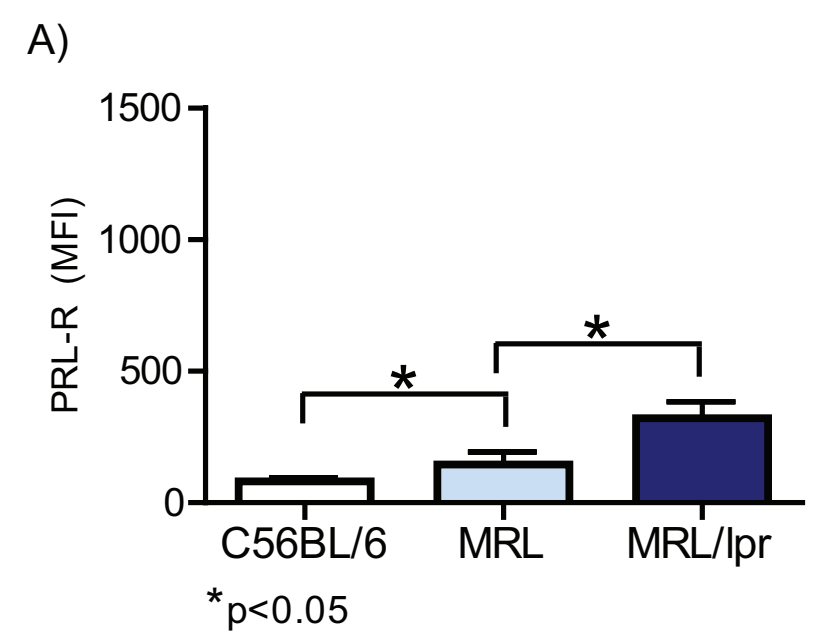

B)

C)
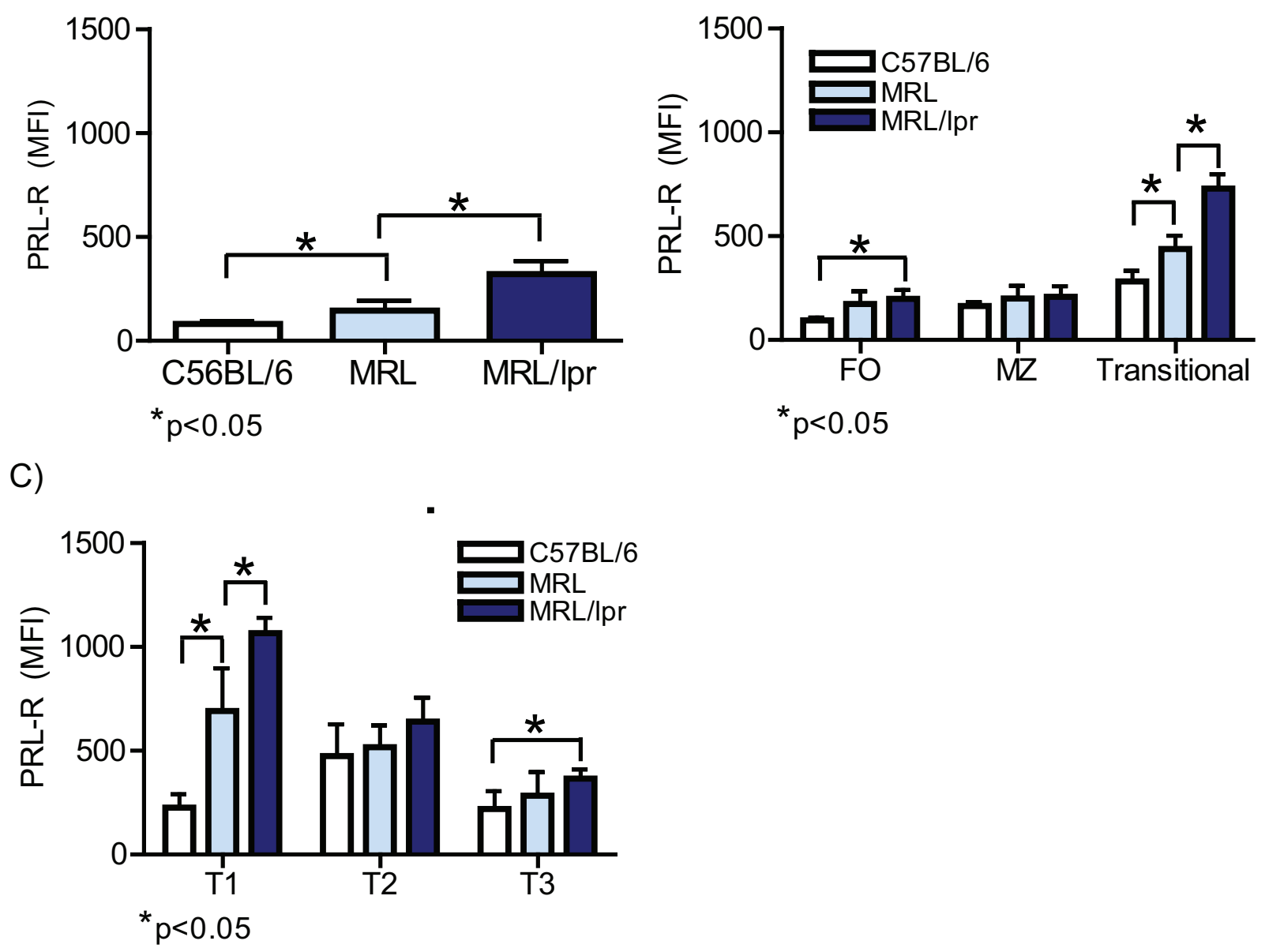

Figure 3 Expression of prolactin receptor in C57BL/6 wild-type, MRL and MRL/Ipr lupus-prone mice. Protein expression of the PRL receptor (PRL-R) was determined by flow cytometry (MFI) from 14 C57BL/6 and MRL/lpr mice and 7 MRL mice. Splenocytes were marked with anti-CD19, anti-CD93, anti-IgM, anti-CD21, anti-CD23, and goat anti-PRL receptor A) splenic B cells; B) Follicular (FO), marginal zone (MZ), transitional B cells; and C) Transitional 1, 2 and 3. Asterisks denote statistical significance with the $p$ value shown.

MFI) and MRL (749.0 $\pm 78.0 \mathrm{MFI})$ mice but not in C57BL/6 (225.5 $\pm 32.3 \mathrm{MFI})$ mice. We found similar levels of PRL receptor expression in T2 cells from MRL/ lpr $(640.0 \pm 59.0 \mathrm{MFI})$, MRL $(551.3 \pm 75.5 \mathrm{MFI})$ and C57BL/6 (482.8 \pm 159.0 MFI) mice, while T3 cells from the MRL/lpr mice showed the highest level (365.8 \pm 43.7 MFI), followed by MRL (310.4 $\pm 56.8 \mathrm{MFI})$ and C57BL/6 mice $(206.6 \pm 94.3 \mathrm{MFI})$. Of all the splenic B cell subsets, T1 cells from the MRL/lpr strain displayed the highest expression of the PRL receptor (Figure 3C).

Induction of hyperprolactinaemia results in an early onset of SLE in the disease-prone MRL/lpr and MRL mice and correlates with the increased expression of the PRL receptor in transitional $B$ cells

Nine-week-old MRL/lpr, MRL and C57BL/6 mice were treated with metoclopramide for six weeks to induce high levels of PRL in the serum before testing for accelerated SLE symptoms. The serum concentration of PRL in the C56BL/6 strain was $0.8 \pm 0.4 \mathrm{ng} / \mathrm{ml}$ before treatment and $1.4 \pm 0.9 \mathrm{ng} / \mathrm{ml}$ when treated with PBS, while mice treated with metoclopramide showed PRL concentrations that were 10-fold higher than those before treatment $(8.1 \pm 0.9 \mathrm{ng} / \mathrm{ml})$. In the MRL mice, the serum PRL concentration was $12.5 \pm 1.9 \mathrm{ng} / \mathrm{ml}$ before treatment, $11.2 \pm 1.8 \mathrm{ng} / \mathrm{ml}$ when treated with PBS, and $26.2 \pm 2.7 \mathrm{ng} / \mathrm{ml}$ after being treated with metoclopramide. In MRL/lpr mice, the serum PRL concentration was $9.1 \pm 2.4 \mathrm{ng} / \mathrm{ml}$, and this concentration increased to $15.4 \pm 2.7 \mathrm{ng} / \mathrm{ml}$ in mice treated with PBS and to $29.6 \pm$ $5.3 \mathrm{ng} / \mathrm{ml}$ in mice treated with metoclopramide. Although an increase in the PRL concentration was observed in the MRL/lpr mice treated with PBS (mice at 15 weeks of age), this increase did not reach the levels 


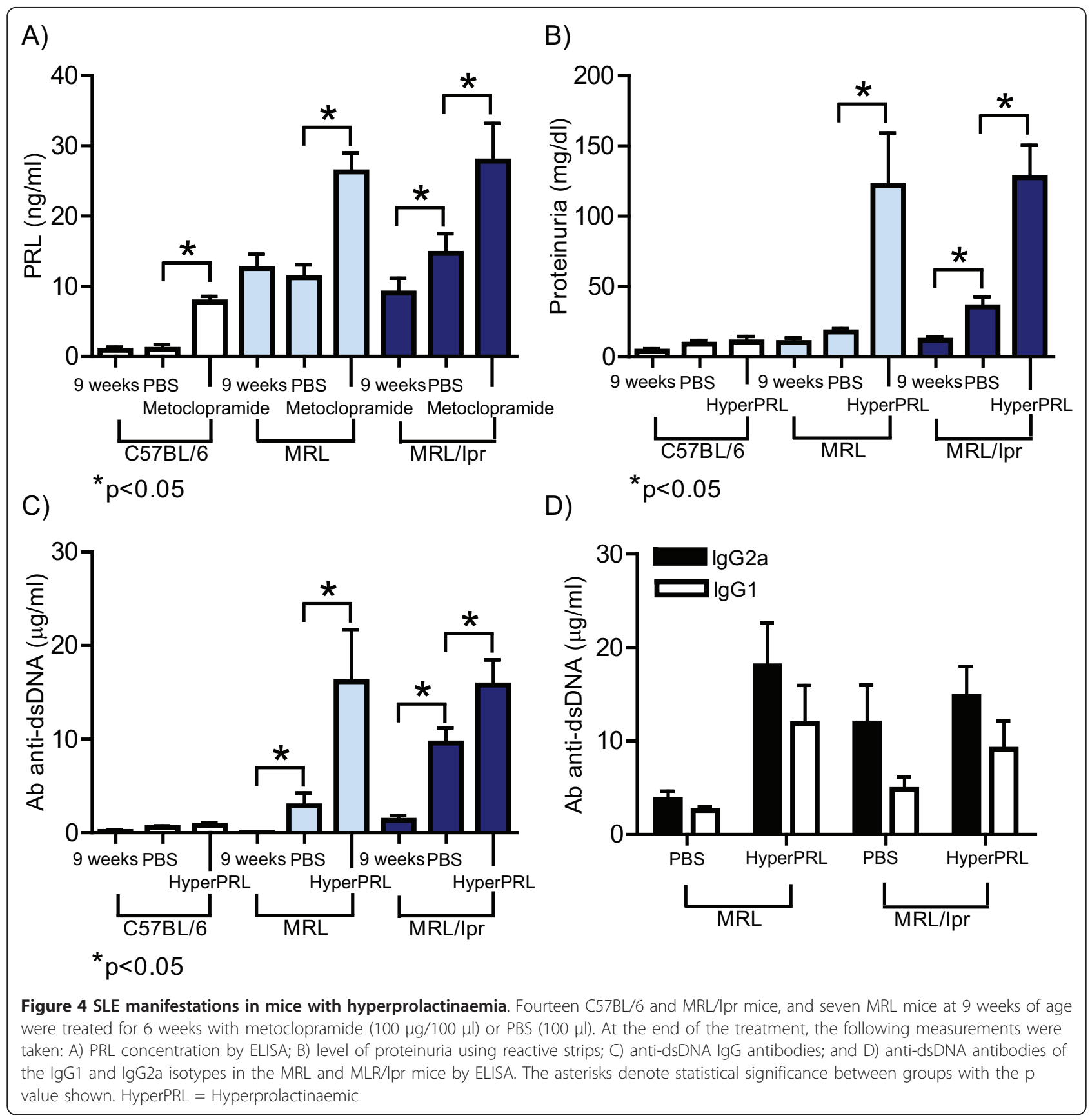

observed in animals treated with metoclopramide (Figure 4A). The consistent increase in the serum concentration of PRL in metoclopramide-treated mice was considered to constitute hyperprolactinaemia and correlated with the premature onset of disease symptoms in lupus-prone mice (see below).

Lupus manifestations were compared in all mouse strains before and after metoclopramide and PBS treatments. The MRL/lpr mice treated with PBS developed proteinuria $(50.8 \pm 15.7 \mathrm{mg} / \mathrm{dl})$, constituting a significant increase compared to the beginning of the treatment
$(12.5 \pm 4.6 \mathrm{mg} / \mathrm{dl}) . \mathrm{MRL} / \mathrm{lpr}$ mice treated with metoclopramide showed a greater increase in proteinuria (104.3 $\pm 30.7 \mathrm{mg} / \mathrm{dl}$ ). By comparison, MRL mice developed proteinuria after metoclopramide treatment (118.5 \pm $37.4 \mathrm{mg} / \mathrm{dl}$ ) but not PBS treatment. Metoclopramidetreated, PBS-treated and untreated mice were tested for serum concentrations of anti-dsDNA antibodies of the IgG isotype. A significant increase in anti-dsDNA antibodies was observed in hyperprolactinaemic MRL/lpr mice $(16.0 \pm 2.9 \mu \mathrm{g} / \mathrm{ml})$ compared to mice treated with PBS $(9.5 \pm 1.6 \mu \mathrm{g} / \mathrm{ml})$ and the levels found at the 
beginning of the treatment $(1.3 \pm 0.5 \mu \mathrm{g} / \mathrm{ml})$. At the beginning of treatment in MRL mice, we did not detect the presence of anti-dsDNA antibodies. However, we observed low concentrations of anti-dsDNA antibodies after PBS treatment $(3.2 \pm 1.8 \mu \mathrm{g} / \mathrm{ml})$, and these concentrations increased significantly in hyperprolactinaemic mice $(15.1 \pm 5.6 \mu \mathrm{g} / \mathrm{ml})$. The C57BL/6 mice did not develop proteinuria after PBS or metoclopramide treatment, and we did not detect anti-dsDNA antibodies under any condition studied (Figure $4 \mathrm{~B}$ and $\mathrm{C}$ ). The main antibody isotypes found in both lupus-prone strains were IgG2a and, to a lesser degree, IgG1 (Figure $4 \mathrm{D})$. No statistically significant differences were found in the production of anti-dsDNA antibodies of the IgM isotype (data not shown). Taken together, these data indicate that metoclopramide treatment induces hyperprolactinaemia and that this state was associated with early manifestations of SLE in the lupus-prone MRL and MRL/lpr mice.

Next, we tested PRL receptor expression in whole splenic B cell populations from the hyperprolactinaemic and PBS-treated control mice. However, we did not find any differences in PRL receptor expression in C57BL/6 mice regardless of age or treatment. In contrast, we found that MRL/lpr mice with hyperprolactinaemia showed a significant increased by more than two-fold in PRL receptor expression compared to mice treated with PBS. Therefore, hyperprolactinaemia correlated with upregulation of the PRL receptor in splenic B cell populations. Interestingly, in the MRL/lpr lupus-prone mice, the normal manifestations of SLE occur at 25 weeks of age. When we compared PRL receptor expression in splenic B cells from hyperprolactinaemic mice (15 weeks of age) and untreated diseased mice (25 weeks of age), no differences were found. We found no differences in PRL receptor expression between the C57BL/6 and MRL/lpr strains at 9 weeks of age. In contrast, there was a statistically significant increase in PRL receptor expression in MRL/lpr mice at 15 and 25 weeks of age $(\mathrm{p}<0.05)$ (Figure 5).

During hyperprolactinaemia, there was a significant increase in PRL receptor expression in MRL/lpr and MRL mice but not in C56BL/6 mice (Figure 6A). In addition, correlating with the expression patterns of the PRL receptor in non-hyperprolactinaemic conditions (Figure 3), transitional B cells seemed to be the main cells responding to the high levels of PRL by further increasing expression of the PRL receptor. Of the transitional B cells, T1 B cells were the population with the highest increase in PRL receptor expression levels in MRL/lpr [1105.7 \pm 79.9 (9 weeks) vs. $1650.2 \pm 232.4$ MFI (hyperprolactinaemia)] and MRL mice (749.0 \pm 78.0 vs. $3407.2 \pm 273.2 \mathrm{MFI}$ ), although all transitional B cell populations displayed increased PRL receptor

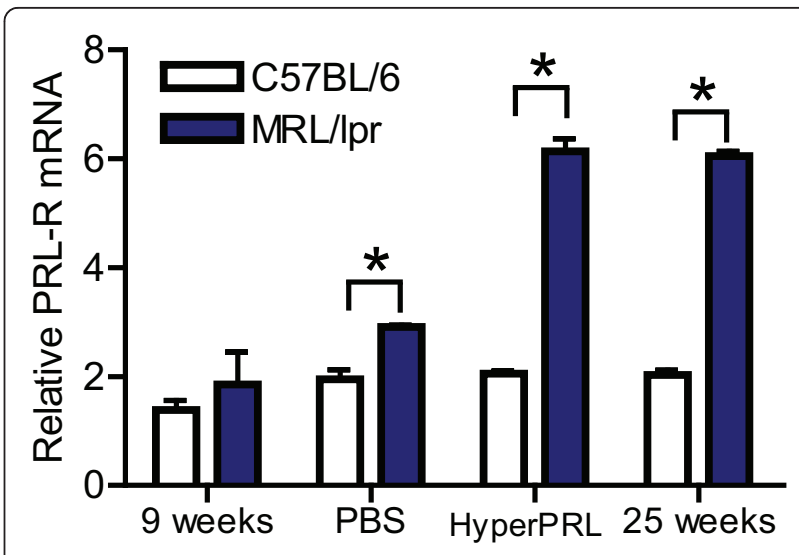

Figure 5 Prolactin receptor expression in MRL/Ipr mice at different ages. Ten C57BL/6 and ten MRL/lpr mice were treated with metoclopramide $(100 \mu \mathrm{g} / 100 \mu \mathrm{l})$ for 6 weeks

[hyperprolactinaemia (HyperPRL)] or PBS (control). Splenic B cells were purified using negative selection from treated and untreated mice: at 9 and 25 weeks of age (untreated) and 15 weeks of age, mice were treated with metoclopramide or PBS (expression of the PRL receptor was determined by real-time PCR [mRNA]). The asterisks denote statistical significance between populations with the $p$ value shown.

expression in the hyperprolactinaemic state in MRL/lpr [T2 (640.0 \pm 59.0 vs. $1266.8 \pm 300.9 \mathrm{MFI})$ and T3 (365.8 \pm 43.7 vs. $756.0 \pm 249.7 \mathrm{MFI})]$ and MRL $[\mathrm{T} 2(551.3 \pm$ 75.5 vs. $2938.6 \pm 145.1 \mathrm{MFI})$ and T3 $(310.4 \pm 56.8$ vs. $1251.6 \pm 521.6 \mathrm{MFI}$ )] mice (Figures 6B, C). No significant changes were observed in the mature splenic $\mathrm{B}$ cell populations. These data suggest a role for PRL in B cell development, mainly in splenic transitional B cells, that correlates with premature manifestations of SLE.

\section{MZ, but not FO, B cells are altered in untreated and hyperprolactinaemic MRL/lpr lupus-prone mice}

Given that the greatest level of PRL receptor expression was found in immature developing splenic B cells, we evaluated whether PRL influences the absolute number of these cells. In agreement with a role for PRL in developing splenic B cells, we found that hyperprolactinaemic $\mathrm{MRL} / \mathrm{lpr}$ mice showed an increase in the absolute number of B cells $\left(158.2 \pm 27.2 \times 10^{6}\right.$ cells $)$ compared to untreated mice $\left(82.7 \pm 13.19 \times 10^{6}\right.$ cells $)$. However, no significant difference was found in mice treated with PBS at 15 weeks of age $\left(113.0 \pm 29.7 \times 10^{6}\right.$ cells $)$. Similarly, hyperprolactinaemic MRL mice showed an increase in the absolute number of B cells $(104.6 \pm 21.3$ $\times 10^{6}$ cells) compared to untreated mice $(69.9 \pm 4.7 \times$ $10^{6}$ cells $)$ and PBS-treated mice $\left(59.8 \pm 19.1 \times 10^{6}\right.$ cells $)$ (Figure 7A). Due to the different levels of PRL receptor expression in the different splenic B cells populations, we analysed each B cell subset individually. Figure 7B shows the mature MZ and FO B cell pools before and 


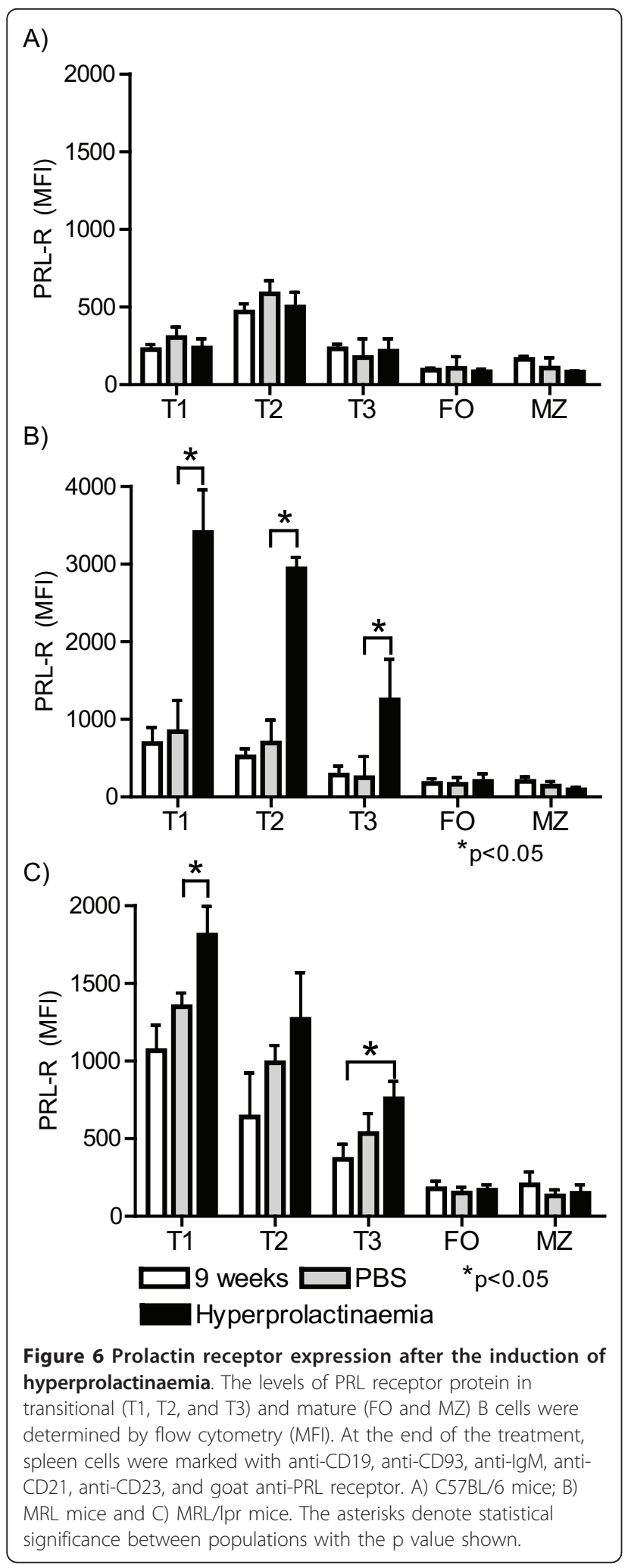

after metoclopramide and PBS treatment in wild type C57BL/6, MRL and MRL/lpr mice. When these mature $B$ cell subsets were quantified, MZ B cells in MRL/lpr mice showed an increase in absolute numbers that correlated with the development of disease 15 weeks of age compared to 9 week mice $\left(12.5 \pm 6.5 \times 10^{6}\right.$ and $26.7 \pm$ $4.0 \times 10^{6}$ cells, respectively), but no further significant increases were found in MZ B cells from mice with hyperprolactinaemia $\left(35.5 \pm 16.2 \times 10^{6}\right.$ cells $)$. In MRL mice, we did not observe any differences between mice 9 weeks and those treated with PBS; however, hyperprolactinaemic mice showed an increase in the absolute number of MZ cells (Figure 7C). No differences in FO B cell numbers were detected regardless of the mouse strain or treatment tested (Figure 7D). Similarly, we did not detect any changes in the absolute numbers of FO or MZ B cells from C57BL/6 mice (Figures 7C, and 7D).

\section{Prolactin preferentially targets transitional-1 B cells and} increases their absolute numbers in the spleen

The largest difference in the absolute number of splenic $\mathrm{B}$ cell was found in T1 B cells, correlating with the high level of PRL receptor expression observed in this population. Figure 8A displays the transitional populations and Figure $8 \mathrm{~B}$ displays the greater than two-fold increase in the absolute number of $\mathrm{T} 1 \mathrm{~B}$ cells in the hyperprolactinaemic MRL/lpr mice compared to PBStreated mice $\left(1.5 \pm 0.2 \times 10^{6}\right.$ cells and $0.7 \pm 0.4 \times 10^{6}$ cells, respectively). The same phenotype was observed in MRL mice, in which the absolute number of T1 B cells only increased in the hyperprolactinaemic mice $[1.3 \pm$ $0.1 \times 10^{6}$ cells (hyperprolactinaemic) and $0.6 \pm 0.10 \times$ $10^{6}$ cells (PBS)]. In contrast, the absolute number of T2 $B$ cells was not affected by hyperprolactinaemia in any of the strains, as shown in Figure 8C. Moreover, a small but significant increase was found in T3 B cells (Figure 8D) from hyperprolactinaemic MRL/lpr mice $(0.8 \pm 0.3$ $\times 10^{6}$ cells $)$ and MRL mice $\left(0.6 \pm 0.1 \times 10^{6}\right.$ cells $)$ compared to that in cells from PBS-treated mice [MRL/lpr $\left(0.4 \pm 0.1 \times 10^{6}\right.$ cells $)$ and MRL $\left(0.3 \pm 0.1 \times 10^{6}\right.$ cells $\left.)\right]$. As expected, there were no differences in the absolute numbers of T1, T2 or T3 B cells between the different treatment groups in C57BL/6 mice. Taken together, these data support a role for PRL in B cell development through the regulation of the size of the T1 B cell pool in the spleen.

\section{Discussion}

Several studies have demonstrated a role for prolactin (PRL) and B cells in the development of autoimmune diseases such as systemic lupus erythematosus (SLE) 


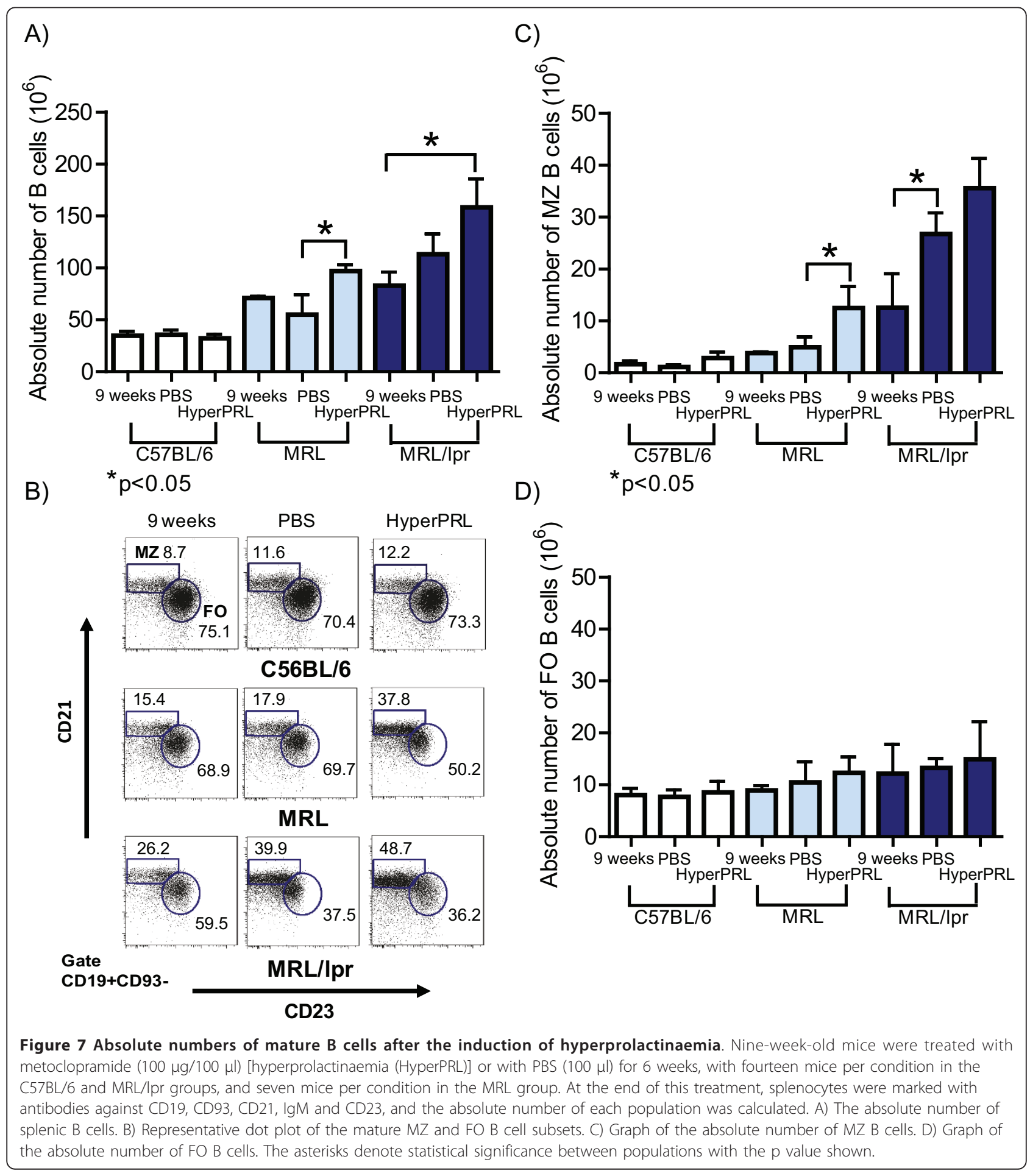

$[6-9,12,13,18,20,21,23,24]$. In this study, we evaluated how PRL affects the course of SLE development in MRL/lpr, MRL, and wild-type mice and observed how this finding correlates with changes in the different splenic $B$ cell subsets. The MRL/lpr strain has a mutation in the Fas gene and develops a disease similar to SLE [25].
MRL mice also exhibit autoimmune disorders despite carrying a normal Fas gene, but the symptoms manifest much later in life than in MRL/lpr mice [19]. To our knowledge, this study is the first to address PRL receptor expression in all of the different subsets of splenic B cells. 


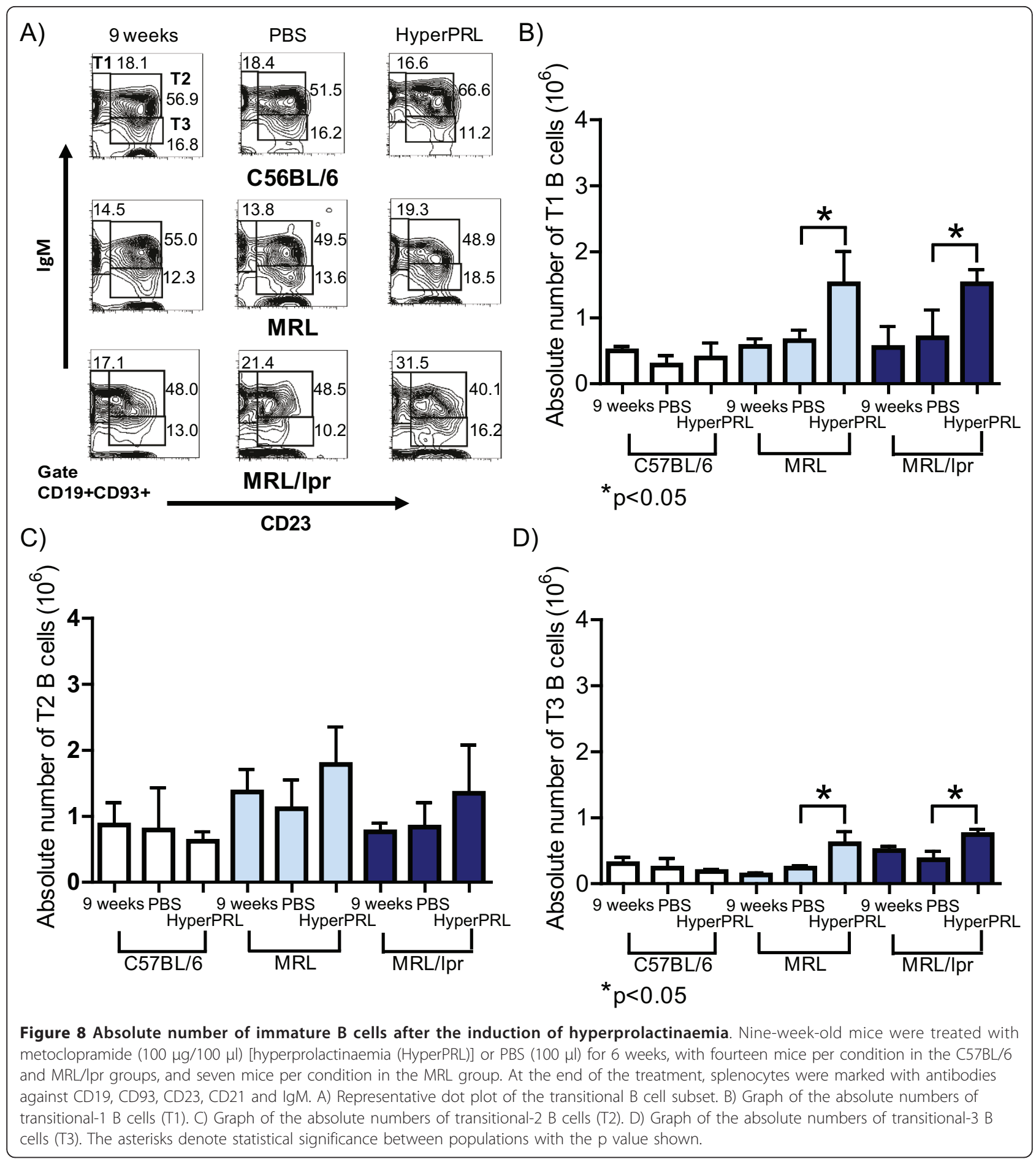

Interestingly, expression of the PRL receptor followed a similar pattern in B cells from wild-type C57BL/6, SLE-prone MRL/lpr and MRL mice. Expression of the PRL receptor varied according to the B cell developmental stage. The highest expression of the PRL receptor was observed in the immature, transitional splenic B cells. Our findings are consistent with those reported by
Morales et al. [26], who transfected proB cells with the PRL receptor triggered their progression to the preB stage through incubation with PRL. Taken together, data from Morales et al. and our group suggest that PRL participates in early B cell differentiation. Our results showed that the pattern of PRL receptor expression levels in transitional B cells was different in 
C56BL/6 mice and the lupus-prone mouse strains. T2 cells showed higher expression of the PRL receptor in C7BL/6, while in lupus-prone strains the T1 cells showed higher expression. These data argue that there is altered expression of the PRL receptor in different B cells subsets during the autoimmune process. Furthermore, the differential presence of the receptor in transitional populations in C56BL/6 mice suggests a regulatory role for PRL in these cells under non-pathological conditions.

Transitional $\mathrm{B}$ cells are constantly testing their antigen receptors (BCR) to identify $B$ cell clones expressing receptors with self-specificity [27]. These clones then trigger different intrinsic mechanisms that eliminate this self-specificity. The MRL strains have a genetic background prone to develop a disease similar to SLE either earlier in life in the case of MRL/lpr mice or later in the case of MRL mice. We found that the T1 B cell subset in both of these strains had the most PRL receptor protein expression. Therefore, it is possible that increased PRL receptor expression at this stage in lupus-prone strains could promote both the rescue of autoreactive clones and B cell developmental progression, thus favouring the development of lupus symptoms. This observation is in agreement with the fact that PRL receptor signalling increases the expression of the antiapoptotic gene Bcl-2 $[28,29]$ and that T1 B cells from hyperprolactinaemic ovariectomised BALB/c mice are more resistant to apoptosis than those from PBS-treated mice [30]. Future experiments should address the molecular role of PRL in this population and better define its contribution in autoimmune disease.

C57BL/6, MRL and MRL/lpr mice treated with metoclopramide showed a further increase in their serum PRL levels that was only accompanied by increased levels of anti-dsDNA antibodies and proteinuria in the MRL/lpr and MRL lupus-prone strains. These findings are in agreement with previous reports studying other hyperprolactinaemic and SLE models, such as reports by McMurray et al. [18,31] who showed hyperprolactinaemia induced by pituitary gland transplantation in NZB $\times$ NZW mice, and a report by Peeva et al. using recombinant PRL to induce hyperprolactinaemia in Sle3/5 R4A$\gamma 2 \mathrm{~b}$ C57BL/6 mice [32]. Additionally, our data are consistent with several clinical trials showing that a high serum PRL level correlated with SLE disease activity $[7,33,34]$.

In our study, PRL receptor mRNA expression was increased in metoclopramide-treated 15-week-old MRL/ lpr mice to a level similar to that found in untreated 25week-old mice displaying high disease activity. This correlation between PRL receptor levels and the degree of disease suggests that PRL plays an important role in the development and exacerbation of SLE. These results also support the idea that the PRL receptor could be useful as an SLE prognostic marker.

Although our results showed that the T2 subset of B cells express the highest levels of the PRL receptor in the spleens of C57BL/6 mice, the absolute number of T2 cell and other B cell subsets and overall PRL receptor expression were not affected by hyperprolactinaemia, and SLE was not induced. This result differs from previous reports by Peeva et al. and Saha et al. describing decreased T1 B cell frequencies and increased T2 B cell frequencies after the induction of hyperprolactinaemia, while the MZ and FO mature B cell pools were unaffected $[30,35]$. This finding may be due to the different experimental approaches used, in that different mouse strain was used (BALB/c), BALB/c mice were ovariectomised, a procedure that eliminates oestrogen and progesterone and affects immune responses [36,37]. In addition, we treated mice with metoclopramide to induce the hyperprolactinaemic state, whereas Peeva and Saha used ovine PRL.

In our study, hyperprolactinaemia resulted in up-regulation of PRL receptor expression and a significant increase in the absolute numbers of $\mathrm{T} 1 \mathrm{~B}$ cells in the MRL/lpr mice. PBS-treated mice did not show increases in the absolute number of $\mathrm{T} 1$ cells, despite an increase in PRL receptor expression, we believe that this is because the level of PRL receptor expression in PBStreated mice never reached the levels found in either pharmacologically induced or age-related hyperprolactinaemic mice. Additionally, in the MRL strain, the absolute number of $\mathrm{T} 1$ cells only increased in hyperprolactinaemic mice, correlating with the early onset of lupus symptoms and increased PRL receptor expression. A similar observation has been noted in NK cell lines, in which high PRL receptor expression correlates with an enhanced capacity of the cells to proliferate [38]. This finding is also in agreement with the observation that the T1 population expresses the highest level of PRL receptor expression before treatment and with other studies showing this subset to be more resistant to apoptosis in mice with hyperprolactinemia [30]. Thus, our data and that of others [30,38,39] support the importance of PRL in B cell development, in developmental associated processes such as proliferation and resistance to negative selection and in the progression of SLE. These findings highlight the idea that this disease originates at different levels, as indicated by its multifaceted nature.

We also found that hyperprolactinaemia increased the expression of the PRL receptor and, to a lesser degree, the absolute numbers of T3 B cells. T3 B cells are considered by Merrel to be a subset of anergic $B$ cells produced by the interaction of the BCR and self-antigens and are not a part of the maturation pathway of $B$ cells 
$[40,41]$. The T3 B cell subset is decreased in MRL/lpr mice, and this decrease has been proposed to be due to self-reactive clones escaping from an anergic state in this mouse strain. This diminished T3 population was described in 9-week-old mice; however, this time point is prior to disease onset, and these mice were compared to the genetically unrelated BALB/c strain [42]. Therefore, future work should determine the effect, if any, of PRL signalling in this population and may generate interesting results.

The number of MZ B cells in MRL/lpr mice increased with age and coincided with the course of the disease, as previously reported [43]. Higher levels of serum PRL induced a further increase in the MZ B cell population, although this change was not significant when compared to mice of the same age treated with PBS. However, this increase in the absolute number of MZ cells was statistically significant in hyperprolactinaemic-MRL mice. These results are consistent with a model in which PRL increases the expression of its receptor mainly in immature transitional $\mathrm{B}$ cells, leading to self-reactive cell maturation with a potential bias toward the MZ type.

Although PRL did not affect the absolute number of mature B cells or their PRL receptor expression pattern, self-reactive clones were more active in hyperprolactinaemic MRL/lpr and MRL mice as shown by an increased concentration of anti-dsDNA antibodies, specifically of the IgG isotype. It will be interesting to discern the function of PRL in the MZ and FO mature populations, as it is clear that they perform different functions. While MZ B cells are part of the innate immune system and preferentially respond to $T$ cellindependent antigens, FO B cells perform the classic functions of adaptive immunity. MZ B cells have mainly been associated with the expression of IgM antibodies $[44,45]$.

Our results show that both MRL/lpr and MRL mice develop an early onset of lupus symptoms after induction of hyperprolactinemia. Although the MRL/lpr strain has an additional mutation in Fas $[19,46]$, our results also suggest that this genetic change most likely has little, if any, effect on the accelerated lupus development. It is possible that strong PRL signalling in immature T1 $B$ cells from both mice strains could potentially trigger rescue from apoptosis induced by recognition of selfantigens and could also shape and promote their differentiation into specific mature B cell populations. The presence of self-reactive clones in MZ B cells correlates with autoimmune diseases [47].

\section{Conclusions}

Our data support a role for PRL in B cell development by primarily affecting the size of the $\mathrm{T} 1 \mathrm{~B}$ cell pool in the spleen. Although PRL exhibits pleiotropic effects in different organs, our results are consistent with a preferential effect in the regulation of the PRL receptor in the T1 population that is responsible for the observed altered B cell development and premature onset of SLE symptoms. Understanding the molecular mechanisms resulting in the development of SLE will help to design prevention, treatment and follow-up strategies for this disease.

\section{Methods \\ Mice}

All studies were approved by the Animal Care Committee of Instituto Nacional de Ciencias Médicas y Nutrición "Salvador Zubiran" and Hospital de Pediatría, Centro Médico Nacional Siglo XXI IMSS, and all of the measurements taken from the mice were in accordance with approved guidelines established by Mexico (Norma Oficial Mexicana NOM-062-ZOO-1999) and the NIH Guide for the Care and Use of Laboratory Animals. The C57BL/6 mice were purchased from Harlan (Indianapolis, USA), and the MRL/MpJ FAS ${ }^{1 p r}$ (MRL/lpr) and MRL/MpJ (MRL) mice were purchased from the Jackson Laboratory (Maine, USA). All of the mice were housed in a specific pathogen-free barrier facility and were provided sterile food and water ad libitum.

\section{Antibodies}

The following antibodies were used: anti-mouse CD21FITC (7 G6) and CD21-APC (7 G6) were from BD Biosciences (Mountain View CA, USA); CD93-PE (AA4.1), CD23-biotinylated, IgM-APC (11/41), CD19-Cy7 (1D3), CD23-PE-Cy7 (B3B4), CD19-FITC (eBioD3), and IgMbiotinylated (11/41) were from eBioscience (San Diego CA, USA); goat anti-mouse PRL-R (E20) was from Santa Cruz Biotechnology (Santa Cruz CA, USA); and swine anti-goat-biotinylated was from Invitrogen (Carlsbad CA, USA). The biotinylated secondary antibody was detected with streptavidin-phycoerythrin-Cy5.5 from BD Biosciences (Mountain View CA, USA).

\section{Purification of B cells}

Single-cell suspensions were prepared from spleens. After red blood cell lysis with lysing buffer (Sigma Aldrich, St. Louis Missouri, USA), the cells were incubated with anti-CD43 (Ly-48) microbeads (Miltenyi Biotec, Bergisch Gladbach, Germany) and the B cells were isolated using negative selection with a magnetic activated cell-sorting (MACS) system (Miltenyi Biotec, Bergisch Gladbach, Germany). After depletion, > 98\% of the remaining cells were $\mathrm{CD} 19^{+}$by flow cytometry.

\section{Cell sorting}

Single-cell suspensions of B cells were incubated with fluorescently labelled antibodies specific for CD19, 
CD93, CD21, CD23, and IgM in staining buffer (PBS with $0.5 \% \mathrm{BSA}$ ) for 20 minutes at $4{ }^{\circ} \mathrm{C}$. The cells were washed, and the $\mathrm{B}$ cell $\left(\mathrm{CD} 19^{+}\right)$subsets were isolated according to the expression of the following surface markers: marginal zone $\left(\mathrm{CD}^{-} 3^{-}, \mathrm{CD} 21^{\text {high }}, \mathrm{CD} 23^{-}\right)$; follicular (CD93- CD21 $\left.{ }^{\text {int }}, \mathrm{CD} 23^{\text {high }}\right)$; transitional-1 (CD93 ${ }^{+}$, $\left.\mathrm{IgM}^{\text {high }}, \mathrm{CD} 23^{-}\right)$; transitional-2 $\left(\mathrm{CD}^{+} 3^{+}, \mathrm{IgM}^{\text {high }}, \mathrm{CD} 23^{+}\right)$; and transitional-3 $\left(\mathrm{CD}^{+} 3^{+}, \mathrm{IgM}^{\text {low }}, \mathrm{CD} 3^{+}\right)$. Cell sorting was performed using a FACSAria sorter with FACSDiva software (BD Bioscience). The purity of the sorted cells ranged from $95 \%$ to $98 \%$.

\section{Real-time PCR}

Total RNA was extracted from B cells of C57BL/6 and MRL/lpr mice using TRIzol reagent (Invitrogen, Carlsbad CA, USA), according to the manufacturer's protocol, and the RNA concentration was determined using UV spectrophotometry. Next, $1 \mu \mathrm{g}$ of total RNA was used to generate cDNA with SuperScript II reverse transcriptase (Invitrogen, Carlsbad CA, USA), according to the manufacturer's specifications. The PRL receptor cDNA was amplified by real-time PCR using a LightCycler TaqMan Master kit (Roche Diagnostic, Mannheim, Germany), according to manufacturer's specifications and using hydrolysis probes and primers designed by Roche Diagnostic. The following primers were used: PRL-R 5'-CAGTAAATGCCACGAACGAA-3' (left); PRL-R 5'-GAGGAGGCTCTGGTTCAACA-3' (right); $\beta$ actin 5'-AAGGCCAACCGTGAAAAGAT-3' (left); and $\beta$-actin 5'-GTGGTACGACCAGAGGCATAC-3' (right). The final volume of the reaction was $10 \mu \mathrm{l}$, and a LightCycler instrument was used to perform the PCR reaction (Roche Diagnostic). The following PCR conditions were used: 10 minutes at $95^{\circ} \mathrm{C}$, followed by 40 cycles of 10 seconds at $95^{\circ} \mathrm{C}, 30$ seconds at $60^{\circ} \mathrm{C}$, and 1 second at $72^{\circ} \mathrm{C}$ and 1 cycle cooled for 30 seconds at $40^{\circ} \mathrm{C}$. The samples were normalised to the $\beta$-actin gene. The relative expression of the PRL receptor was calculated using the $2 \Delta \mathrm{CT}$ formula.

\section{Induction of hyperprolactinaemia}

Groups of 14 female, 9-week-old C57BL/6 and MRL/lpr mice and 7 female MRL mice were given a daily subcutaneous injection of $100 \mu \mathrm{g}$ of metoclopramide (Sigma Aldrich, St Louis MO, USA) in $100 \mu$ of PBS for six weeks. A matched control group (C57BL/6, MRL and MRL/lpr) received only PBS $(100 \mu l)$ over the same period. Urinary protein levels were assessed semiquantitatively using reagent strips for urinalysis (Uri-Quick Stanbio Laboratory, Kendall TX, USA). Serum samples were obtained at the beginning and at the end of the experiments, between 08:00 and 11:00 hours, and kept at $-35^{\circ} \mathrm{C}$ until assayed for prolactin and anti-DNA antibodies.

\section{Prolactin assessment}

Serum levels of prolactin were detected using ELISA. The 96-well maxisorp plates (Nunc, Rochester NY, USA) were coated overnight with $100 \mu \mathrm{l}$ of $4 \mu \mathrm{g} / \mathrm{ml}$ anti-mouse prolactin monoclonal antibody (clone 207518, R\&D Systems, Minneapolis MN, USA) in PBS at $4^{\circ} \mathrm{C}$, blocked with $2 \%$ bovine serum albumin (Invitrogen, Carlsbad CA, USA), and incubated with the serum sample $(1: 10)$ overnight at $4{ }^{\circ} \mathrm{C}$. Recombinant mouse prolactin (National Hormone and Peptide Program, $\mathrm{NIH}$, donated by AF Parlow) was used as a standard. The plates were then incubated with $0.1 \mu \mathrm{g} / \mathrm{ml}$ biotinylated anti-prolactin antibody ( $R$ \& D Systems, Minneapolis MN, USA), avidin-alkaline phosphatase (Zymed Laboratories, San Francisco CA, USA) and 5-bromo-4chloro-3 indolyl phosphate (Sigma-Aldrich, St Louis MO, USA) as a substrate, according to the manufacturer's instructions. The OD was monitored at $405 \mathrm{~nm}$ using a Dynatech MR5000 ELISA reader.

\section{Determination of anti-DNA antibodies}

Anti-dsDNA antibody serum concentrations were detected using ELISA. A 96-well maxisorp plate (Nunc, Rochester NY, USA) was coated with $100 \mu \mathrm{l}$ of $2.5 \mu \mathrm{g} / \mathrm{ml}$ calf thymus dsDNA (Sigma Aldrich, St Louis MO, USA) in bicarbonate buffer overnight at $4^{\circ} \mathrm{C}$ and was blocked with $2 \%$ bovine serum albumin (Invitrogen, Carlsbad CA, USA). The plates were then incubated for $1 \mathrm{~h}$ at $37^{\circ} \mathrm{C}$ with serum (1:50) or the anti-dsDNA antibody standard (clone 16-13, Chemicon International, Billerica MA, USA), followed by rabbit anti-mouse IgG, IgG1, IgG2a or anti-mouse IgM conjugated to alkaline phosphatase (Zymed Laboratories, San Francisco CA, USA) and substrate ([5-bromo-4-chloro-3- indolyl phosphate; SigmaAldrich, St Louis MO, USA]). The OD was monitored at $405 \mathrm{~nm}$ using a Dynatech MR5000 ELISA reader.

\section{Cell surface staining and flow cytometry}

Splenocytes were incubated with fluorescently labelled antibodies for 20 minutes at $4^{\circ} \mathrm{C}$ in staining buffer (PBS with $0.5 \%$ BSA and $0.01 \%$ sodium azide). The cells were then washed and fixed in 2\% paraformaldehyde (Sigma Aldrich, St Louis MO, USA). The data were acquired using a FACSAria flow cytometer (BD Bioscience) and analysed with FlowJo software (Tree Star, Ashland OR, USA).

\section{Statistical analysis}

The data were analysed with standard statistical tests (mean value, SD, Student's $t$ test, and ANOVA), and the 
results are expressed as the mean $\pm \mathrm{SD}$. The level of significance was set at $p \leq 0.05$. All calculations were performed using SPSS 15 software.

\section{Acknowledgements}

We are very grateful to Dr. A.F. Parlow (National Hormone and Peptide Program, NIH) for providing us with recombinant mouse prolactin. This work was supported in part by Consejo Nacional de Ciencia y Tecnología [CONACYT 49798-M] and Fondo de Investigación en Salud [FIS/IMSS/202 and FIS/IMSS/PROT/517]

\section{Author details}

'Unidad de Investigación Médica en Inmunología, Hospital de Pediatría, CMN Siglo XXI, IMSS. Av Cuauhtemoc 330. Col. Doctores, Mexico, D.F. CP06720, Mexico. ${ }^{2}$ Unidad de Investigación Médica en Enfermedades Infecciosas y Parasitarias, Hospital de Pediatría, CMN Siglo XXI, IMSS. Av Cuauhtemoc 330. Col. Doctores, Mexico, D.F., Mexico. ${ }^{3}$ Departamento de Investigación Experimental y Bioterio del Instituto Nacional de Ciencias Médicas y Nutrición "Salvador Zubirán", Vasco de Quiroga 15, Col Tlalpan, Mexico, D.F. Mexico, ${ }^{4}$ Unidad de Investigación Médica en Inmunoquímica, Hospital de Especialidades, CMN Siglo XXI, IMSS. Av Cuauhtemoc 330. Col. Doctores, Mexico, D.F., Mexico. ${ }^{5}$ Departamento de Inmunología, Escuela Nacional de Ciencias Biológicas, IPN. Prolongación de Carpio y Plan de Ayala s/n Col. Santo Tomas., Mexico D.F., Mexico.

\section{Authors' contributions}

YLS, MVLH, EMD and LCH performed and analysed the experiments, FBF and EMFP interpreted the results and prepared the manuscript preparation, ETC and RHG performed the mouse experiments, LAP performed the cell sorting AKCR contributed to the experimental design, interpretation of results, and manuscript preparation. All of the authors read and approved the final manuscript.

\section{Competing interests}

The authors declare that they have no competing interests.

Received: 24 August 2011 Accepted: 9 March 2012

Published: 9 March 2012

\section{References}

1. Bole-Feysot C, Goffin V, Edery M, Binart N, Kelly PA: Prolactin (PRL) and its receptor: actions, signal transduction pathways and phenotypes observed in PRL receptor knockout mice. Endocr Rev 1998, 19:225-268.

2. Chavez-Rueda K, Hernandez J, Zenteno E, Leaños-Miranda A, LegorretaHaquet MV, Blanco-Favela F: Identification of prolactin as a novel immunomodulator on the expression of co-stimulatory molecules and cytokine secretions on T and B human lymphocytes. Clin Immunol 2005, 116:182-191.

3. Sodhi A, Tripathi A: Prolactin and growth hormone induce differential cytokine and chemokine profile in murine peritoneal macrophages in vitro: involvement of p-38 MAP kinase, STAT3 and NF-kappaB. Cytokine 2008, 41:162-173.

4. Tomio A, Schust DJ, Kawana K, Yasugi T, Kawana Y, Mahalingaiah S, Fujii T, Taketani Y: Prolactin can modulate CD4+ T-cell response through receptor-mediated alterations in the expression of T-bet. Immunol Cell Biol 2008, 86:616-621.

5. Da Costa R, Szyper-Kravitz M, Szekanecz Z, Csépány T, Dankó K, Shapira Y, Zandman-Goddard G, Orbach H, Agmon-Levin N, Shoenfeld Y: Ferritin and prolactin levels in multiple sclerosis. Isr Med Assoc J 2011, 13:91-95.

6. Blanco-Favela F, Chavez-Rueda K, Leaños-Miranda A: Analysis of antiprolactin auto antibodies in systemic lupus erythematosus. Lupus 2001, 10:757-761.

7. Leaños-Miranda A, Pascoe-Lira D, Chavez-Rueda KA, Blanco-Favela F: Persistence of macroprolactinemia due to antiprolactin autoantibody before, during, and after pregnancy in a woman with Systemic Lupus Erythematosus. J Clin Endocrinol Metab 2001, 86:2619-2624.

8. Jara LJ, Benitez G, Medina G: Prolactin, dendritic cells, and systemic lupus erythematosus. Autoimmun Rev 2008, 7:251-255.
9. Orbach H, Zandman-Goddard G, Boaz M, Agmon-Levin N, Amital H, Szekanecz Z, Szucs G, Rovensky J, Kiss E, Doria A, Ghirardello A, GomezArbesu J, Stojanovich L, Ingegnoli F, Meroni PL, Rozman B, Blank M, Shoenfeld Y: Prolactin and autoimmunity: hyperprolactinemia correlates with serositis and anemia in SLE patients. Clin Rev Allergy Immunol 2011, doi: 10.1007/s12016-011-8256-0

10. Sousa GM, Oliveira RC, Pereira MM, Parana R, Sousa-Atta AM: Autoimmunity in hepatitis; C virus carriers: involvement of ferritin and prolactin. Autoimmun Rev 2011, 10:210-213.

11. Buskila D, Berezin M, Gur H, Lin HC, Alosachie I, Terryberry JW, Barka N, Shen B, Peter JB, Shoenfeld Y: Autoantibody profile in the sera of women with hyperprolactinemia. J Autoimmun 1995, 8:415-424.

12. Grammer AC, Lipsky PE: B cell abnormalities in systemic lupus erythematosus. Arthritis Res Ther 2003, 5(Suppl 4):S22-S27.

13. Yurasov S, Wardemann H, Hammersen J, Tsuiji M, Meffre E, Pascual V, Nussenzweig MC: Defective B cell tolerance checkpoints in systemic lupus erythematosus. J Exp Med 2005, 201:703-7011.

14. Montgomery DW: Prolactin production by immune cells. Lupus 2001, 10:665-675

15. Goffin $\mathrm{V}$, Binart $\mathrm{N}$, Touraine P, Kelly PA: Prolactin: the new biology of an old hormona. Annu Rev Physiol 2002, 64:47-67.

16. Günes H, Mastro AM: Prolactin receptor gene expression in rat splenocytes and thymocytes from birth to adulthood. Mol Cell Endocrinol 1996, 117:41-52.

17. Praprotnik S, Agmon-Levin N, Porat-Katz BS, Blank M, Meroni PL, Cervera R, Miesbach W, Stojanovich L, Szyper-Kravitz M, Rozman B, Tomsic M, Shoenfeld Y: Prolactin's role in the pathogenesis of the antiphospholipid syndrome. Lupus 2010, 9:1515-1559.

18. McMurray RW: Prolactin in murine systemic lupus erythematosus. Lupus 2001, 10:742-747.

19. Andrews BS, Eisenberg RA, Theofilopoulos AN, Izui S, McConahey PJ Murphy ED, Roths JB, Dixon FJ: Spontaneous murine lupus-like syndromes. Clinical and Immunophatological manifestations in several strains. J Exp Med 1978, 148:1198-1215.

20. Chan OT, Madaio MP, Shlomchik MJ: B cells are required for lupus nephritis in the polygenic, Fas-intact MRL model of systemic autoimmunity. J Immunol 1999, 163:3592-3594.

21. Li Y, Chen F, Putt M, Koo YK, Madaio M, Cambier JC, Cohen PL, Eisenberg RA: B cell depletion with anti CD79 mAbs ameliorates autoimmune disease in MRL/lpr mice. J Immunol 2008, 181:2961-2972.

22. Allman D, Lindsley RC, DeMuth W, Rudd K, Shinton SA, Hardy RR: Resolution of three no proliferative immature splenic $B$ cell subsets reveal multiple selection points during peripheral $B$ cell maturation. $J$ Immunol 2001, 167:6834-6840.

23. Orbach $\mathrm{H}$, Shoenfeld $\mathrm{Y}$ : Hyperprolactinemia and autoimmune diseases. Autoimmun Rev 2007, 6:537-542.

24. Anaya JM, Shoenfeld Y: Multiple autoimmune diseases in a patient with hyperprolactinemia. Isr Med Assoc J 2005, 7:740-741.

25. Watanabe-Fukunaga R, Brannan Cl, Copeland NG, Jenkins NA, Nagata S Lymphoproliferation disorder in mice explained by defects in Fas antigen that mediates apoptosis. Nature 1992, 356:314-317.

26. Morales P. Carretero MV, Geronimo H, Copín SG, Gaspar ML, Marcos MA Martín-Pérez : Influence of prolactin on the differentiation of mouse Blymphoid precursors. Cell Growth Differ 1999, 10:583-590.

27. Tussiwand R, Bosco N, Ceredig R, Rolink AG: Tolerance checkpoints in Bcell development: Johnny B good. Eur J Immunol 2009, 39:2317-2324.

28. Buckley AR: Prolactin a lymphocyte growth and survival factor. Lupus 2001, 10:684-690.

29. Kochendoerfer SK, Krishnan N, Buckley DJ, Buckley AR: Prolactin regulation of BCl-2 family members: increased expression of bcl-xL but not mcl-1 or bad in Nb2-T cells. J Endocrinol 2003, 178:265-273.

30. Saha S, Gonzalez J, Rosenfeld G, Keiser H, Peeva E: Prolactin alters the mechanisms of B cell tolerance induction. Arthritis Rheum 2009, 60:1743-1752.

31. McMurray R, Keisler D, Kanuckel K, Izui S, Walker SE: Prolactin influences autoimmune disease activity in the female B/W mouse. J Immunol 1991, 147:3780-3787.

32. Peeva E, Gonzalez J, Hicks R, Diamond B: Cutting edge: lupus susceptibility interval Sle $3 / 5$ confers responsiveness to prolactin in C57BL/6 mice. J Immunol 2006, 177:1401-1405. 
33. Jara L, Gómez-Sánchez C, Silvera L, Martínez-Osuna P, Vasey F, Espinoza L: Hiperprolactinemia in systemic lupus erythematosus association with disease activity. Am J Med SC 1992, 303:222-226.

34. Walker SE: Bromocriptine treatment of systemic lupus erythematosus. Lupus 2001, 10:762-768.

35. Peeva E, Michael D, Cleary J, Rice J, Chen X, Diamond B: Prolactin modulates the naive B cell repertoire. J Clin Invest 2003, 111:275-283.

36. De León-Nava MA, Nava K, Soldevila G, López-Griego L, Chávez-Ríos JR, Vargas-Villavicencio JA, Morales-Montor J: Immune sexual dimorphism: effect of gonadal steroids on the expression of cytokines, sex steroid receptors, and lymphocyte proliferation. J Steroid Biochem Mol Biol 2009, 113:57-64.

37. García-Pérez MA, Del Val R, Noguera I, Hermenegildo C, Pineda B, MartinezRomero A, Cano A: Estrogen receptor agonists and immune system in ovariectomized mice. Int J Immunopathol Pharmacol 2006, 19:807-819.

38. Sun R, Li AL, Wei HM, Tian ZG: Expression of prolactin receptor and response to prolactin stimulation of human NK cell lines. Cell Res 2004, 14:67-73.

39. Cohen-Solal JF, Jeganathan V, Hill L, Kawabata D, Rodriguez-Pinto D, Grimaldi C, Diamond B: Hormonal regulation of B-cell function and systemic lupus erythematosus. Lupus 2008, 17:528-532.

40. Cambier JC, Gauld SB, Merrell KT, Vilen BJ: B cell anergy: from transgenic models to naturally occurring anergic B cell. Nat Rev Immunol 2007, 7:633-643.

41. Merrell KT, Benschop RJ, Gauld SB, Aviszus K, Decote-Ricardo D, Wysocki LJ, Cambier JC: Identification of anergic B cells within a wild-type repertoire. Immunity 2006, 25:953-962

42. Teague BN, Pan Y, Mudd PA, Nakken B, Zhang Q, Szodoray P, Howard XK, Wilson PC, Farris D: Cutting edge: transitional T3 $B$ cells do not give rise to mature $B$ cells have undergone selection and are reduced in murine lupus. J Immunol 2003, 178:7511-7515.

43. Blair PA, Chavez-Rueda KA, Evans JG, Shlomchik MJ, Eddaoudi A, Isenberg DA, Ehrenstein MR, Mauri C: Selective targeting of B cells with agonistic anti-CD40 is an efficacious strategy for the generation of induced regulatory T2-like B cells and for the suppression of lupus in MRL/lpr mice. J Immunol 2009, 182:3492-3502.

44. Pillai $\mathrm{S}$, Cariappa A: The follicular versus marginal zone B lymphocyte cell fate decision. Nat Rev Immunol 2009, 9:767-777.

45. Kaminski DA, Stavnezer J: Enhanced IgA class switching in $\mathrm{MZ}$ and $\mathrm{B} 1 \mathrm{~B}$ cells relative to follicular/B2 B cells. J Immunol 2006, 177:6025-6029.

46. Adachi M, Suematsu S, Suda T, Watanabe D, Fukuyama H, Ogasawara J, Tanaka T, Yoshida N, Nagata S: Enhanced and accelerated lymphoproliferation in Fas-null mice. PNAS 1996, 93:2131-2136.

47. Duan B, Niu H, Xu Z, Sharpe AH, Croker BP, Sobel ES, Morel L: Intrafollicular location of marginal zone/CD1 $\mathrm{d}^{\text {hi }} \mathrm{B}$ cells is associated with autoimmune pathology in a mouse model of lupus. Lab Invest 2008, 88:1008-1020.

doi:10.1186/1471-2172-13-11

Cite this article as: Ledesma-Soto et al:: Increased levels of prolactin receptor expression correlate with the early onset of lupus symptoms and increased numbers of transitional- $1 \mathrm{~B}$ cells after prolactin treatment. BMC Immunology 2012 13:11.

\section{Submit your next manuscript to BioMed Central and take full advantage of:}

- Convenient online submission

- Thorough peer review

- No space constraints or color figure charges

- Immediate publication on acceptance

- Inclusion in PubMed, CAS, Scopus and Google Scholar

- Research which is freely available for redistribution

Submit your manuscript at www.biomedcentral.com/submit
Biomed Central 